\title{
Media, Business Education and E-Learning: An Insinuative Overview
}

\section{Md. Ekram Hossin}

Senior Officer, Shipping and Logistics Department, Babylon Group, Dhaka, BANGLADESH

*E-mail for correspondence: ekram_14@yahoo.com

Received: Oct 18, 2015;

Accepted: Nov 02, 2015;

Published: Jan 18, 2016

Source of Support: Nil

No Conflict of Interest: Declared

\begin{abstract}
Media, education, and e-language are interrelated. Media is the right medium to make profitable business activities. Education enlightens the heart of people and business education can make the people learn about the proper ways of business. So, these three are correlated. Mass media plays a significant role in shaping public perceptions on a variety of important issues in business education. They also function in influencing modern business culture and education by selecting and portraying a particular set of beliefs, values, and traditions as reality. Mass media plays an important role in business education. Business has a noble position as an ideal occupation. Mass media helps to enhance the range of business education for the development of the country as well as the world. This descriptive and analytic research work finds out the insinuative and synchronic synopsis of media, education and e-language.
\end{abstract}

Keywords: Present condition, Involvement of community media, Business education, Importance of Business Education

JEL Classifications Code: M19

\section{INTRODUCTION}

Education does not only mean schooling. Even though many would agree that schooling is essential, yet education is a much wider concept embracing formal and informal methods of learning, traditional and nontraditional teaching processes, self-learning (through various media such as books, journals, TV, Internet, etc). Thus, it is doubtful whether anyone can argue against the importance of education. Some may argue against formal education processes. The alternatives, however, have not provided mainstream solutions. Therefore, even on this issue, one has to recognize its importance.

We cannot think about business without media and business education without Islamic rules. Business education and communication in the modern world facilitate an awareness of the new and unconventional. Social media has played a growing role in company's business communication and education. Numerous affordable advantages create increased sales and customer loyalty through different platforms and word of mouth. In changing the style and scale of possible discourse, they reconfigure the nature of religious thought and action, create new forms of public space and encourage debate over meaning. Mass education and mass communications are important in all contemporary Islamic higher education and business education. However, the full effects of mass media in higher education, especially business education, only began to be felt in much of the Islamic world since mid-century also in our country considerably later.

Mass media refers collectively to all media technologies, including the Internet, television, newspapers, film and radio, which are used for mass communications, and to the organizations which control these technologies. This raises an inescapable challenge for schools. As part of their mission to help prepare young people to turn into better conversant and more perceptive analytical thinkers, educators should seriously consider making media literacy an essential part of schooling the minimum, enhancing students' aptitude to use media more decisively. Specifically, students have to develop an indulgent of the ways in which the media deal with the theme of diversity. Media teaches and assists us through information; ideas; disseminating values; creating and reinforcing anticipations, and providing models for performance.

\section{BACKGROUND AND REVIEW}

Media plays a useful function both through the information that is dispensed through them, and through the interpretations they place upon this information. (Vipond, 2000) There are two main types of media.

Electronic media: Electronic Media is information or data that is created, distributed and accessed using a form of electronics, electromechanical energy or any equipment 
used in electronic communications. The common equipment we use on a day to day basis to access Electronic Media is our television, radio, computer, cell phones and other devices transporting information to and from us using electronic involvement.

Print media: The print media is private and consists of hundreds of weekly publications, presenting a vast array of viewpoints, though some outspoken papers have faced pressure in the past. English language papers appeal to an educated urban readership. These newspapers are also very useful for wide range learning.

Based on the materials of e-learning and its impacts, enough critical essays and analyzes were published in the shapes of different books and in many literary journals that are very useful as the sustaining materials for the further study of the thesis. Moreover, the different educational and social websites and research journals also remain supportive for the study. Online information about the virtual education or online education system is also proved to be convincing. The only helpful; method was, in fact, the 'observation method' with conceptual analyzes.

\section{OBJective}

The main objective of this study is to focus on the positive effects of media on learning business education and how different forms of media have contributed to the development of humanity through its service for higher business education in present circumstances.

\section{Methodology}

The research follows the two types of the Content Analysis Method: the conceptual analysis and the relational analysis. The research identifies certain concepts for examination and defines these concepts presenting their proper characteristics and explanations that are breaking them into meaningful and pertinent units of information. In fact, for this research work, another helpful method was 'Observation Method'. By using this method, different literary articles, critical compositions, and journals, and websites information are gathered for related study materials, to be acknowledged in the related topics.

\section{Discussion}

\section{Involvement of community media with Education}

In recent years, the impact of media on teaching and learning has increased tremendously. New opportunities are being provided to give a techno-touch to the traditional educational process and system. As the society is becoming media-savvy day by day, the educational modules are being channeled through certain community access centers like community radio system, televisions, the internet, community multi-media centers, and so on. Media has opened new dimensions in learning. Now education is no longer a constraint for anyone. Media has brought education to the doorstep of each and every individual. All forms of media- the newspaper, radio, television and the internet are equally important in imparting education. As the technology is progressing, the different educational modules are being channeled through certain community access centers like community radio system, televisions, the internet, community multi-media centers, etc. (Briggs \& Burke, 2010).

\section{Courses offered by Universities}

The optional course offered by several universities, "Media Literacy", or more specifically "Education in Mass Media," at the academic level aims at enabling the students to study and analyze the functions of mass media in our society. In particular, it focuses on the analysis and research of the structural and functional relationship between the mass media and education - a relationship that appears as dual: on the one hand, education on the mass media, and on the other hand, the role of the mass media concerning the impartment of educational knowledge and research (newspapers, television, etc.) and scientific publications in specific media, such as the scientific journals. The mass media discourse (printed and electronic) is analyzed - for example, newspapers, radio, television and other electronic means, the internet and the alternative press). We will make references to media theories (Marxist, structural-functional, etc.) but we will focus on the Theories of Organization, shedding light to the strategies with which the communication product is produced, distributed and consumed by the public (the audience, the viewers, etc.).

\section{Present Condition of Business Education throughout the World}

Higher business education landscapes in the Islamic world are changing, faster in some of its countries than in others. The new educational landscapes for business are being shaped, colored, and influenced by many factors, especially the political, cultural, technology, economic, and financial factors, both local and global. These offer both opportunities and challenges to the Muslim countries like ours to effectively address their contemporary and future needs in higher education. In tackling the issue of higher business education needs, particularly the needs for world-class universities and other institutions of higher learning, it is important to pay due attention not only to the necessity of wisely used material, financial, and human resources, but also to the desirability of accessing and utilizing Islamic cultural, intellectual, and traditional knowledge resources.

\section{Business Education and its Relevance}

Successful individuals in the business environment usually have a mix of education and experience relating to business concepts and principles. Individuals may spend more time on earning a business education early in their career rather than honing their skills through practical experience. Education can be an invaluable tool 
for building a successful career or specializing in a specific industry or sector. Business education can be earned in a traditional school environment or through informal methods. Traditional business education is earned through a college or university. Common business degrees include a bachelor's in business administration or management, accounting, marketing or international business. Master's degrees are also popular, including the Master of Business Administration, Master of Accountancy or Master of Finance. Informal business education can include certificates earned through trade organizations, reading business related magazines and books or attending a trade school. Business education teaches individuals about traditional and current types of business methods or management techniques. This education helps individuals understand what business methods are successful and why others fail. Educated business owners and managers use this information, so they do not repeat the failed attempts of previous businesses. Business education can also alert individuals to upcoming changes in the business environment. This information can then be translated to other individuals in the workplace.

Hiring individuals with business degrees or extensive business education may cost the company more money. Companies may not be able to afford to hire multiple individuals with the same education or skill set. Many times, companies hire managers with business education and rely on them to transfer their knowledge to front-line employees. Companies may also hire educated business experts who can come in for a day and train employees on specific business tasks, thereby avoiding higher labor costs. Highly educated workforces often create competitive advantages for companies in the business environment. Educated employees can help companies improve operations and possibly find new or better ways to produce goods and services. Employees with a solid business education may also provide companies with internal managerial candidates, allowing companies to promote employees from within rather than conducting extensive recruiting searches for managers. While an individual can be successful in business without a traditional education, earning a college degree does not mean individuals have forsaken business opportunities for a piece of paper. Many business owners and entrepreneurs may go back to college and earn a business degree or enroll in professional education courses that help them advance their business knowledge. (Vitez, 2014)

\section{Online Degrees}

There are several online universities around the world. They offer BBA or MBA degree under business studies faculty. They also offer $\mathrm{M}$. Phil and $\mathrm{Ph}$. $\mathrm{D}$ in the various relevant business fields. Traditional, classroom-based education is not always the best fit for everyone. Some are interested in the online education system. According to the needs of those learners, some universities offer online degrees. Ashford University is one of the nation's premier centers for students interested in obtaining their online degree. Ashford's mission is to provide accessible, affordable, \& innovative learning opportunities to students. Committing itself to providing high-quality online education, University of Phoenix is a great fit for students seeking an accredited online university offering doctoral, masters, bachelors, and associate's degrees. Liberty is the results-focused University that accommodates your lifestyle with quality undergraduate \& graduate programs. Liberty University Online offers a unique approach to online education.

\section{Media and Business Education}

"Education is greatly influenced by media, especially columnists," McCartney said, noting the media's prominent voice on No Child Left Behind, athletics, and the achievement gap. Media literacy does not mean to know about media but to learn something from it. Moreover, we find the subjects of business education that we learn in our curricula are also found in media. They may be related to various business studies fields, different languages, social sciences and health. It also helps to develop critical thinking skills. The students can get a vast exposure to the pop-cultural references. They can get statistics and data from the news, which can be the basis for math and science learning. The teachers can also incorporate media in the classroom as an effect of media is definitely the accumulation of General knowledge, different dialects, and cultures. Television boosts the social awareness of a child to a great extent. Sports channels develop the logical mindset of a child. So, we can have the overall edification of the human mind through media learning. Media is a great device to make the coverage about education. Moreover, business education cannot be existed without the help of media. The internet is getting more and more importance in learning. All learners learn from it in several ways. Books and journals are available on the internet. In fact, it is a great source of knowledge. The condition of business education throughout the world can be easily realized from the level of recent use of the internet. Television channels are broadcasting different news and views about business education for a better economic condition to the society. Almost all the newspapers have a feature business page that shows the overall pictures of business and its relevance to the readers.

\section{FINDINGS}

\section{E-language Matters}

E-language has become popular in these days. Many words are being included in the dictionaries because of the impacts of e-learning and internet using. Some words have been too short for using in the email or Facebook messaging systems. The word 'message' itself has been in a short form in 'msg'. The word 'education' has been 'edn'. The word welcome has been too short as 'wc'. Fine becomes 'f9'; 'tc' symbolizes take care; 'Gd n8' symbolizes 
good night. Our young generation of 21st century accepts these short forms warmly, and thus language gets a great impact on its forms and rules. Even while chatting the teens and youths are using too short forms to understand and exchange opinion quickly. They write " $h \mathrm{r} u$ ?" instead of a full sentence "How are you?" So, the world is getting more and more changed and upgraded.

\section{E-teachers}

E-teachers are now appointed by the well-known universities of the world. Thus, the popular and the most intellectual teachers can teach all over the world using internet facilities. The scholarly teachers of a country can now teach in many institutions of his country at a time and in the universities of other countries as well. As a result understanding and comprehending have been effortless and lucid. The vastness of knowledge is being spread worldwide. Better students and better teachers are repeatedly created. For a prompt example, a renowned Bangladeshi Professor of English at Jahangirnagar University, Dr. M. Maniruzzaman who is adequately specialized in Applied Linguistics and ELT is the Eteacher at University of Maryland, BC in TESOL Methodology and E-teacher (Assessment) at University of Oregon, USA. Likewise, several Indian and American Professors are involved in different e- teaching and training programs round the year. Even conferences and seminars are also being held through online where the teachers and learners all over the world can participate simultaneously.

\section{Business Education: Bangladesh Context}

Specifically business education is still in the primitive stage in Bangladesh compared to other developing nations in Asia. However, the standard is improving but in a very slow pace. Our business schools need to focus more on practical learning rather than theoretical education to help the students get accustomed to the real world. A business student must have a strong communication skill to face the challenge in the competition prevailing in today's world. Unfortunately, this is one area, where our business education failed to improve so far considerably. The second most important factor is the inability to think innovatively. This quality, again, can be achieved through practical education. Books only offer cases and various events in the past, but to survive in today's world one needs to learn about the real business scenario.

\section{Importance of Business Education in outer world}

Business education can be an expensive investment. In the U.S., the average annual tuition for full-time enrollment in a Masters of Business Administration program at a top school was $\$ 46,839$ in 2009 , according to "The Economist." Of course, if you take fewer classes or choose a smaller institution, your costs will be lower. However, you also must factor in the opportunity costs of gaining a business education, such as your decreased income for the duration. If the decision seems daunting, ask other business owners in your field for their input. In the end, your decision will likely come down to whether the total costs are worth the specific benefits a business education provides. Communication skills are vital for success in any business. A business education develops your ability to tailor your messages to different types of audiences. For example, courses in marketing help you create effective campaigns that target specific consumers while courses in corporate communications teach you how to design effective business presentations, lead group meetings and author internal documents for employee guidance.

\section{Conducting Business Activities with Respective to Islamic Laws}

The relationship between Islamic Laws and communist, socialist and capitalist activities depend on the type of the activities and whether these activities include some type of prohibitions in Islam. For example, prohibiting an individual from property rights is unacceptable in Islamic laws. Some types of business conducts in capitalism are common in Islamic activities. These activities include joint partnership and limited partners. However, Islamic laws differ on bonds and preferred shares, because of the privilege given to the bonds and preferred shares that contain fixed interest rate. (Juma'h \& Abu-Mounes, 2011)

\section{The Recent International Financial Instabilities}

The recent international financial instabilities have been severe and far reaching in their magnitude and consequences. Neither any country nor any sector seems to have been spared from their effects. The higher education sector is not an exception; particularly the programs offered in business and finance. Many academics, practitioners and others have started questioning the content of the programs and their impact on the learners. Ethics, values, and responsibility are coming out as factors that cannot be surpassed. Thus, current and future programs ought not to ignore such factors. Within this heated context, Islamic finance education has gained momentum. This phenomenon has been depicted by Western higher learning institutions as an opportunity that could enhance its competitiveness. Consequently, many renowned Universities and business Schools started offering streams at their existing programs or even establishing fully-fledged Islamic Finance ones. This book sheds light on this development through actual cases written by lecturers and researchers who played an important role in the Islamic finance in Western higher education. (Belouafi, Belabes \& Trullols, 2014)

\section{CONCLUSION}

We are in the right path regarding business education. We have a great resource regarding faculty members and very effective secondary, higher secondary and tertiary medium of the education system. All we need is to ensure 
is synchronization between teachers, students, education system and the real world needs for fulfilling the actual purpose of business education. Moreover, for that media is an inevitable part. Mass media can play the most vital role to help to develop our human resources, which will, in return, be able to enhance the reputation of Bangladesh while representing our country abroad in future.

\section{REFERENCES}

Abdullah, A., \& Hossain, M. (2014). Brain Drain: Economic and Social Sufferings for Bangladesh. Asian Journal Of Humanity, Art And Literature, 1(1), 9-17.

Abedin MM, Ahmed AA and Neogy TK. 2012. Mechanism of Accountability and Auditing: Public Sector Scenarios of Bangladesh Journal of Business Studies, 4, 131-148.

Ahmed AA, Siddique MN and Masum AA. 2013. Online Library Adoption in Bangladesh: An Empirical Study University of Bahrain Best Practices in Management, Design and Development of e-Courses: Standards of Excellence and Creativity. Manama: IEEE.

Ahmed, Alim Al Ayub. Accounting in Islamic Perspective: A Timely Opportunity, A Timely Challenge. ASA University Review, Vol. 6 No. 2 July-December 2012

Alalawi, N. (2015). How Media Covered "Arab Spring" Movement: Comparison between the American Fox NEWS and the Middle Eastern Al Jazeera. ABC Journal Of Advanced Research, 4(2), 131-140.

Alam, M., \& Islam, M. (2012). Plan and Policies for Success in the Business World: A Conceptual Study. ABC Journal Of Advanced Research, 1(1), 60-69.

Begum R, Ahmed AA and Neogy TK. 2012. Management Decisions and Univariate Analysis: Effects on Corporate
Governance in Bangladesh Journal of Business Studies, 3, 87115.

Belouafi, Ahmed; Abderrazak, Belabes; Trullols, Cristina. Islamic Finance in Western Higher Education. Palgrave Macmillan. 01.12.2014. Available at http://www.palgrave.com.

Briggs, Asa \& Burke, Peter (2010). Social History of the Media: From Gutenberg to the Internet. Polity Press. pp. 1. ISBN 9780745644950.

Bulbul, A. (2013). Implication of Islamic Law of Inheritance: Ultimate Solution to Family Conflict. Asian Journal Of Applied Science And Engineering, 2(3), 217-224.

Jisun, T., \& Kabir, M. (2014). A Comparative Study on the Preference for Delivery Process in Bangladesh. ABC Journal Of Advanced Research, 3(1), 24-28.

Juma'h, Ahmad. H; Abu-Mounes, Raed. N. An Introduction to the Islamic Perspectives of Conducting Business. Revista Empresarial Inter Metro/ Inter Metro Business Journal. Vol: 7, No: 1, Spring-2011. p 61-62.

Mack, Stan. Importance of Business Education. $2^{\text {nd }}$ December, 2014. Available at http://smallbusiness.chron.com Online document. 29.11.2014. Available at http:/ / bangladeshcorporate.blogspot.com

Miah, M. (2015). A Framework of Global e-Learning for the Advanced Generations. Asian Business Review, 1(2), 145-151.

Vipond (2000) p.88; "Mass media", Oxford English Dictionary, Online Version. November 2010.

Vitez, Osmond. eHow Contributor. Importance of Business Education. (25.11.2014) Available at: http:/ / www.ehow.com Yunus, M. (2015). A Comparative Study on Public- Private Partnership (PPP) for Creating Highly Skilled and Productive Business Graduate in Bangladesh. Asian Business Review, 3(3), 21-25.

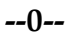




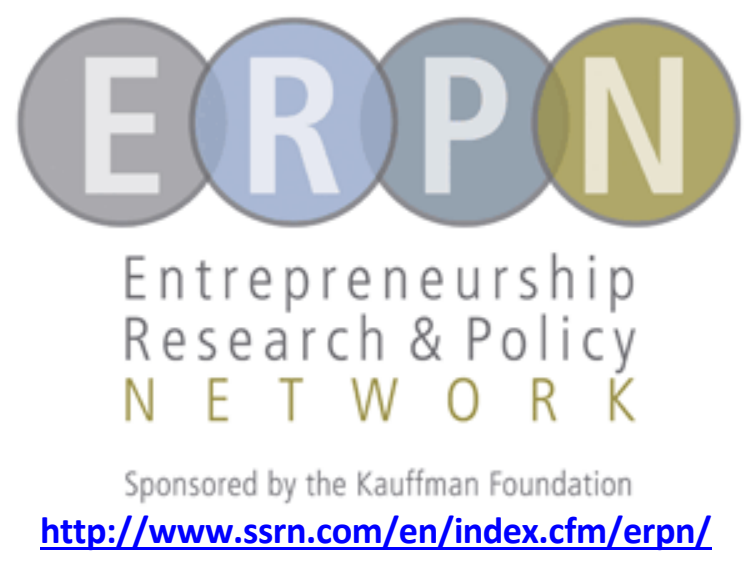

American Journal of Trade \& Policy has joined Partners in Publishing Journals within the Entrepreneurship Research \& Policy Network (ERPN) in SSRN.

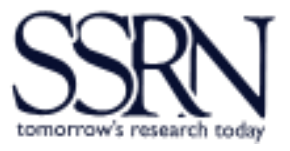

\section{SOCIAL SCIENCE RESEARCH NETWORK \\ 2171 Monroe Avenue, Suite 203, Rochester, NY 14618, USA http://www.ssrn.com/en/}

AJTP Link: http://www.ssrn.com/link/American-Journal-Trade-Policy.html 